\title{
SOSIALISASI UNDANG-UNDANG NOMOR 11 TAHUN 2008 TENTANG INFORMASI TRANSAKSI ELEKTRONIK IBU-IBU PKK RW 20 KELURAHAN BUNULREJO KOTA MALANG
}

\author{
Fullchis Nurtjahjani, Abdullah Helmy, Eny Widiyowati, R. Sugeng Basuki, Ane Fany Novitasari \\ fullnurtjahjani@gmail.com, anefany.novita98@gmail.com
}

\begin{abstract}
Abstrak - Perkembangan teknologi dan informasi akhir-akhir ini, membawa banyak perubahan dalam dunia bisnis. Salah satu bentuk perubahan yang terjadi dalam dunia bisnis adalah munculnya sistem transaksi baru yang disebut e-commerce atau transaksi elektronik. E-commerce merupakan model bisnis terbaru yang lebih praktis, melalui media internet, dan tidak menghadirkan pelaku bisnis secara fisik.
\end{abstract}

Kata kunci: Teknologi, e-commerce, bisnis

\section{PENDAHULUAN}

\subsection{Latar Belakang}

E-commerce juga membawa perubahan terhadap para pelaku bisnis yang selama ini menjalankan usahanya di dunia nyata, kemudian mengembangkan usaha tersebut ke dunia maya (virtual). Perubahan ini ditandai dengan munculnya berbagai "online shop" dalam situs-situs internet. Dalam sistem ini, pelaku usaha memasang iklan produk yang dijual pada internet, dan konsumen yang tertarik dengan produk tersebut selanjutnya menghubungi pelaku usaha yang bersangkutan untuk melakukan kesepakatan jual beli, termasuk mengenai cara pengiriman barang dan cara pembayaran. Perubahan drastis ini jelas mempengaruhi gaya hidup manusia yang semula dari alam nyata beralih ke dunia maya. Berbelanja di online shop dirasakan lebih mudah dan praktis untuk sebagian besar orang.

Pendapat di atas hampir sama dengan definisi transaksi elektronik yang diatur dalam Pasal 1 ayat (2) Undang-undang Nomor 11 Tahun 2008 tentang Informasi dan Transaksi Elektronik, yang dirumuskan sebagai berikut: "Transaksi Elektronik adalah perbuatan hukum yang dilakukan dengan menggunakan Komputer, jaringan Komputer, dan/atau media elektronik lainnya.

Perlindungan hukum terhadap konsumen merupakan hal yang penting mengingat posisi tawar konsumen yang lemah dalam suatu hubungan bisnis. Lemahnya posisi tawar pada konsumen dapat disebabkan oleh beberapa hal, antara lain kurangnya wawasan konsumen serta kurang berfungsinya aparat penegak hukum. Aparat penegak hukum masih lemah dalam mengawasi penerapan peraturan dalam rangka melindungi hak-hak konsumen. Perlindungan hukum terhadap kosumen itu sendiri dilaksanakan berdasarkan asas-asas perlindungan konsumen sebagaimana yang telah diatur dalam Pasal 2 Undangundang Nomor 8 Tahun 1999 tentang Perlindungan Konsumen, yang dirumuskan sebagai berikut
"Perlindungan konsumen berasaskan manfaat, keadilan, keseimbangan, keamanan dan keselamatan konsumen, serta kepastian hukum". Untuk itulah diperlukan peningkatan pengetahuan dan pemahaman masyarakat khususnya terutama keluarga terhadap peraturan perundang-undangan yang terkait dengan masalah perlindungan konsumen dan informasi terkait transaksi elektronik tersebut, sehingga mempunyai kesadaran dan perhatian untuk dapat ikut berperan aktif membantu pemerintah dalam menanggulangi masalah transaksi elektronik. Kebutuhan akan hal tersebut sangat besar dihadapi oleh setiap anggota masyarakat terutama kelompok kerja - kelompok kerja (pokja-pokja) seperti yang ada di RW 20 Kelurahan Bunulrejo, Kota Malang dan sangat mendesak untuk segera diwujudkan. Salah satu upaya mewujudkan kebutuhan akan peningkatan pengetahuan masyarakat terhadap perlindungan konsumen transaksi elektronik adalah dengan mengadakan pelatihan dan sosialisasi atau penyadaran hukum terhadap perlindungan konsumen transaksi elektronik pada anggota masyarakat RW 20 Kelurahan Bunulrejo, Kota Malang,.

Politeknik Negeri Malang sebagai instrument bagian dari masyarakat yang merupakan lembaga institusi pendidikan bertugas memberikan pendidikan kepada masyarakat sebagai bentuk kepedulian sosial. Oleh karena itu dilakukan program pengabdian kepada masyarakat dengan materi:. Sosialisasi UndangUndang Nomor 11 Tahun 2008 Tentang Informasi dan Transaksi Elektronik di RW 20 Kelurahan Bunulrejo, Kecamatan Blimbing, Kota Malang,. Hasil dari kegiatan ini diharapkan mampu menjadi solusi permasalahan dengan harapan dapat melindungi konsumen dalam transaksi elektronik.

\subsection{Permasalahan Mitra}

Maraknya ketidaksesuaian pembelian barang yang dibeli melalui situs online membuat banyak masyarakat resah akan hal tersebut khususnya ibu-ibu PKK RW 20, Kelurahan Bunulrejo Kota Malang, sehingga penulis ingin memberikan informasi terkait hal tersebut dengan cara mensosialisasikan UndangUndang Nomor 11 Tahun 2008 Tentang Informasi dan Transaksi Elektronik. 


\section{TINJAUAN PUSTAKA}

\subsection{Pengertian Elektronik Internet}

Elektronik internet menurut Julian Ding sebagaimana dikutip oleh Mariam Darus Badrul Zaman menentukan bahwa: Transaksi Elektonik internet adalah elektronik dagang antara penjual dengan pembeli untuk menyediakan barang, jasa atau mengambil alih hak. Kontrak ini dilakukan dengan media elektronik dimana para pihak tidak hadir secara fisik dan medium ini terdapat dalam jaringan umum dengan system terbuka yaitu internet atau world wide web. Transaksi ini terjadi terlepas dari batas wilayah dan syarat nasional.

\subsection{Sifat - Sifat dan Karakteristik E-commerce}

- Transparan;

- Interaktif; dan

- Cepat.

Raiport dan Jaworski berpendapat bahwa karaktristik e-commerce merupakan informasi digital atau digital information, artinya pertukaran informasi digital antara para pihak yang trjadi dalam proses komunikasi, serta koordinasi antara prusahaan dngan individu dalam jual beli barang dan jasa dan pngiriman barang, sebagai berikut:

Technology enabled, dalam e-commerce transaksi-transaksi yang terjadi dimungkinkan oleh adanya teknologi.

Technologi mediated, e-commerce merupakan mekanisme perdagangan yang tidak hanya dimungkinkan dengan adanya teknologi akan tetapi ecommerce juga merupakan hubungan yang menggunakan teknologi sebagai media sehingga keberhasilan e-commerce sangat ditntukan dengan bergantung kepada beberapa baik teknologi dan alat yang dipergunakan.

\subsection{Jenis Transaksi E-commerce}

Transaksi melalui elektronik secara tidak langsung yaitu hubungan hukum antara pembeli dan penjual yang merupakan pembuatan kontrak melalui internet akan tetapi pengiriman barang dilakukan secara biasa yang umumnya dilakukan dalam perdagangan barang;

Transaksi melalui elektronik langsung yaitu hubungan hukum yang dilakukan lewat internet baik pembuatan kontrak maupun pengiriman barang biasanya dalam perdagangan biasa misalnya penjualan piranti lunak, film, musik atau informasi yang dapat di download

\subsection{Keuntungan dan Kerugian E-commerce}

Bagi Kalangan Pengusaha

- E-commerce dapat memperluas pasar sampai dengan tingkat internasional dengan modal kecil karena melalui internet para pengusaha dengan mudah, cepat dan murah bisa mendapatkan lebih banyak konsumen;

- E-commerce memungkinkan perusahaan untuk menurunkan jumlah persedian barang (inventory) dan kelebihan persedian barang (overhead) karena penyimpanan barang akan tergantung pada pemesanan konsumen;
- E-commerce dapat meningkatkan efesiensi perusahaan dengan meningkatakan tingkat produktifitas pegawai-pegawai di bagian penjualan dan adminitrasi;

- E-commerce dapat menekan biaya komunikasi karena biaya penggunan internet jauh lebih murah;

- E-commerce dapat meningkatakan citra perusahaan dengan semakin baiknya pelayanan pada konsumen, ditemukannya mitra-mitra bisnis baru, proses kerja yang lebih sederhana dan bertambah cepatnya akses akses brbagai informasi.

\section{Bagi Konsumen}

- E-commerce memungkinkan para konsumen untuk berbelanja atau melakukan transaksi lainya selama 24 jam untuk seluruh lokasi di seluruh dunia.

- E-commerce memberikan lebih banyak pilihan bagi para konsumen.

- E-commerce umumnya menawarkan barangbarang atau jasa-jasa dengan harga yang relatif lebih murah.

- Di dalam sektor jasa pengiriman produk-produk lebih cepat. 5. Konsumen dapat tukar-menukar informasi.

\section{Bagi Masyarakat}

- Perdagangan elektronik memberikan manfaat terhadap masyarakat sebagai berikut:

- E-commerce memungkinkan banyak orang untuk bekerja di rumah mereka.

- E-commerce memungkinkan sejumlah pedagang untuk menjual barang-barang atau jasa mereka dengan harga yang lebih murah sehingga orang dapat membeli produk dan jasa.

- E-commerce dapat menjangkau konsumen yang berada di daerah-daerah terpencil.

- E-commerce dapat menfasilitasi pemberian layanan-layanan publik seperti misalnya perawatan kesehatan, pendidikan, pendistribusian layanan-layanan sosial.

Perdaganngan secara elektronik selain memberikan keuntungan juga dapat mengakibatkan kerugian yakni:

\section{Secara Teknis}

- Kurang terjaminya keamanan dan reabilitas sistem, termasuk keamanan dan reabilitas standar.

- Kurang memadainya insfrastruktur.

- Bagi vendor memerlukan web server dan insfrastruktur lainya dan server jaringan.

\section{Secara hukum}

- Masih adanya beberapa permasalahan hukum yang belum terpecahkan peaturan perundangundangan yang dibuat oleh pemerintah negaranegara cenderung belum sempurna untuk menjangkau beberapa permasalahan hukum seperti terjadinya masalah sengketa dalam perdagangan elektronik yang sifatnya lintas batas. 
- Keamanan dan privasi perdagangan elektronik dapat merugikan pihak konsumen terutama dalam akses informasi pribadi konsumen.

\subsection{Hukum Perlindungan Konsumen}

Hukum perlindungan konsumen dewasa ini mendapat cukup perhatian karena menyangkut aturanaturan guna mensejahterakan masyarakat, bukan saja masyarakat selaku konsumen saja yang mendapatkan perlindungan, namun pelaku usaha juga mempunyai hak yang sama untuk mendapatkan perlindungan, masing masing ada hak dan kewajiban. Pemerintah berperan mengatur, mengawasi, dan mengontrol, sehigga tercipta sistem yang kondusif saling berkaitan satu dengan yang lain dengan demikian tujuan menyejahterakan masyarakat secara luas dapat tercapai

\subsection{Azas dan Tujuan Perlindungan Konsumen}

Sebagai salah satu bagian dari Sesuai dengan pasal 2 Undang-Undang tentang Perlindungan Konsumen menyatakan perlindungan konsumen berazaskan manfaat, keadilan, keseimbangan, kemanan dan keselamatan konsumen, serta kepastian hukum.

Perlindungan hukum kepada konsumen merupakan hal yang semakin penting disebabkan antara lain faktor-faktor pertama, kedudukan konsumen yang relatif lemah dibanding produsen. Kedua, perkembangan ilmu pengetahuan dan teknologi sebagai motor penggerak produktifitas dan efesiensi produsen dalam menghasilkan barang dan jasa. Ketiga, perubahan konsep pemasaran yang mengarah pada pelanggan dalam kontek lingkungan eksternal yang lebih luas pada situasi ekonomi global

\subsection{Pengertian Konsumen}

Pengertiankonsumen dalam undang-undang perlindungan konsumen dijelaskan apa yang dimaksud dengan konsumen yaitu: "Konsumen adalah setiap orang pemakai barang dan/atau jasa yang tersedia dalam masyarakat, baik bagi kepentingan diri sendiri, keluarga, orang lain, maupun makhluk hidup lain dan tidak untuk diperdagangkan". Perlindungan kerja untuk masa sebelum bekerja, meliputi penyusunan kontrak kerja dan pengerahan/penempatan tenaga kerja.

\subsection{Pengertian Pelaku Usaha}

Pengertian pelaku usaha dalam undangundang perlindungan konsumen adalah: "Pelaku Usaha adalah setiap orang perseorangan atau badan usaha, baik yang berbentuk badan hukum maupun bukan badan hukum yang didirikan dan berkedudukan atau melakukan kegiatan dalam wilayah hukum Negara Republik Indonesia, baik sendiri maupun bersama-sama melalui perjanjian penyelenggaraan kegiatan usaha dalam berbagai bidang ekonomi”.

\subsection{Tanggung Jawab Pelaku Usaha dan Ganti Rugi Kepada Konsumen}

Pelaku usaha dalam menjalankan usahanya dan sebagai penyedia barang dan/atau jasa ditengah-tengah masyarakat mempunyai tanggung jawab terhadap barang dan/atau jasanya yang dikonsumsi oleh konsumen, terlebih lagi apabila tanggung jawab itu muncul akibat kesalahan yang ditimbulkan oleh pelaku usaha atas barang dan/atau jasa yang dikonsumi konsumen, yang megakibatkan konsumen mengalami kerugian. Dengan demikian penyelenggara transaksi elektronik sebagai pelaku usaha mempunyai pertaggungjawaban kepada konsumen terhadap adanya kerugian-kerugian yang dialami konsumen terhadap barang/atau jasa yang dikonsumsinya

\subsection{Upaya Hukum dalam Transaksi E-commerce}

Dalam melindungi konsumen dalam transaksi $e$ commerce juga dapat ditempuh dengan upaya hukum. Upaya hukum ini digunakan apabila telah terjadi sengketa antara pelaku usaha dengan konsumen. Menurut UUPK salah satu hak konsumen adalah mendapatkan advokasi, perlindungan dan upaya penyelesaian sengketa secara patut.28 Selain itu, salah satu kewajiban pelaku usaha adalah memberikan kompensasi, ganti rugi dan/atau penggantian atas kerugian akibat penggunaan, pemakaian, dan pemanfaatan barang dan/atau jasa yang diperdagangkan

\section{SOLUSI DAN TARGET LUARAN}

\subsection{Solusi}

Beberapa solusi yang dapat ditawarkan untuk mengatasi kendala yang dihadapi adalah sebagai berikut :

- Memberikan bekal pengetahuan dan membuka wawasan bagi Ibu-ibu PKK RW 20 Kelurahan Bunulrejo Kota Malang agar mengetahui informasi terkait transaksi elektronik.

- Melakukan tindakan preventif pada Kasus Jual Beli Online.

- Menjalin hubungan yang lebih erat antara Politeknik Negeri Malang dengan masyarakat khususnya Ibu-ibu PKK RW 20 Kelurahan Bunulrejo Kota Malang.

\subsection{Target Luaran}

Tabel 1 rencana target capaian PKM DIPA Kemitraan Masyarakat

\begin{tabular}{|c|l|l|}
\hline No & \multicolumn{1}{|c|}{ Jenis luaran } & $\begin{array}{c}\text { Indikato } \\
\mathbf{r} \\
\text { capaian }\end{array}$ \\
\hline \multicolumn{2}{|c|}{ Luaran wajib } & $\begin{array}{l}\text { accepted } \\
\text { bublikasi di jurnal nasional } \\
\text { seminar nasional }\end{array}$ \\
\hline 2 & $\begin{array}{l}\text { Publikasi pada media } \\
\text { massa cetak/ online/ } \\
\text { repocitory Polinema }\end{array}$ & Belum \\
\hline 3 & Peningkatan daya saing & Belum \\
\hline
\end{tabular}




\begin{tabular}{|c|l|l|}
\hline & $\begin{array}{l}\text { (peningkatan kualitas, } \\
\text { kuantitas, seta nilai tambah } \\
\text { barang, jasa, diversifikasi } \\
\text { produk atau sumber } \\
\text { lainnya) }\end{array}$ & \\
\hline 4 & $\begin{array}{l}\text { Peningkatan penerapan } \\
\text { Iptek di masyarakat } \\
\text { (mekanisme, IT dan } \\
\text { manajemen) }\end{array}$ & Belum \\
\hline 5 & $\begin{array}{l}\text { Perbaikan tata nilai } \\
\text { masyarakat ( seni budaya, } \\
\text { sosial, politik, keamanan, } \\
\text { ketentraman, pendidikan, } \\
\text { kesehatan) }\end{array}$ & Belum \\
\hline 1 & $\begin{array}{l}\text { Publikasi di jurnal } \\
\text { internasional }\end{array}$ & $\begin{array}{l}\text { Tidak } \\
\text { ada }\end{array}$ \\
\hline 2 & $\begin{array}{l}\text { Jasa, rekayasa sosial, } \\
\text { metode atau sistem, } \\
\text { produk/barang }\end{array}$ & Belum \\
\hline 3 & Inovasi baru TTG & Belum \\
\hline 4 & Hak kekayaan intelektual & Belum \\
\hline 5 & Buku ber ISBN & Belum \\
\hline & \multicolumn{2}{|l}{} \\
\hline Luaran tambahan & \\
\hline
\end{tabular}

\section{HASIL DAN LUARAN YANG DICAPAI}

\subsection{Pelaksanaan Kegiatan}

Sasaran yang dicapai pada kelompok atau individu peserta pelatihan adalah diharapkan nantinya menjadi bekal dalam menjalankan tugas dan pekerjaannya sebagai ketua pimpinan dan pengurus Kelurahan Bunulrejo Kota Malang sebagai konsumen yang mengerti tentang cara memberikan perlindungan terhadap dirinya sendiri dalam transaksi elektronik atau dengan kata lain memberikan perlindungan hukum bagi dirinya. Dampaknya anggota PKK RW 20 dan masyarakat sekitar akan menjadi konsumen yang cerdas dan tanggap.

Setelah mengadakan Pengabdian Kepada Masyarakat,maka untuk melihat keberhasilannya harus dilihat dari hasil dan dampak dari kegiatan tersebut. Saat ini memang harus diakui hasilnya belum nampak,tapi berdasarkan hasil pengamatan selama ini kemajuan sudah mulai ada, ditunjukkan dengan adanya Ibu-ibu PKK RW 20 kelurahan Bunulrejo Kota Malang yang mulai teliti dan waspada dalam melakukan pembelian online. Kegiatan ini dapat dilakukan baik secara formal maupun non formal dengan insentif perjam, per acara, per minggu dan per bulan.

Dengan rata-rata peserta pengabdian masyarakat adalah ibu-ibu dengan usia 30-55 tahun, tingkat pendidikan SMP, SMA, S1, S2, Sarjana dan sederajat dapat dikatakan secara akademis termasuk pendidikan menengah dan pendidikan tinggi sehingga metode pelatihan yang digunakan mudah dimengerti dan mudah dilaksanakan..

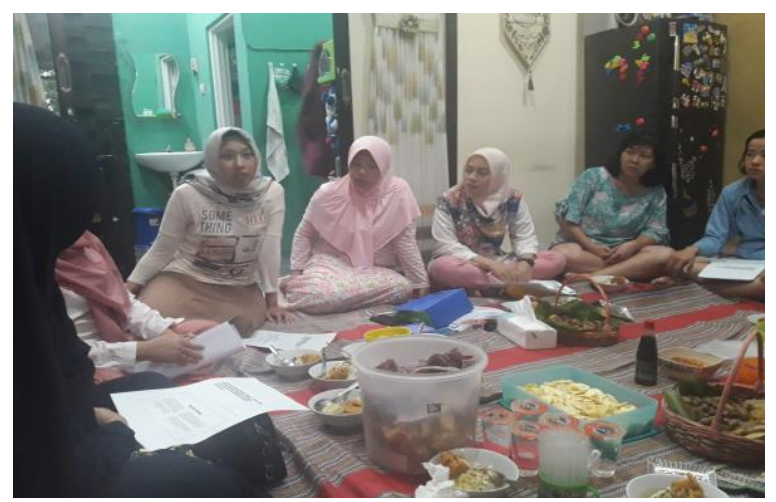

Gambar 1. Sosialisasi Ibu PKK RW 03

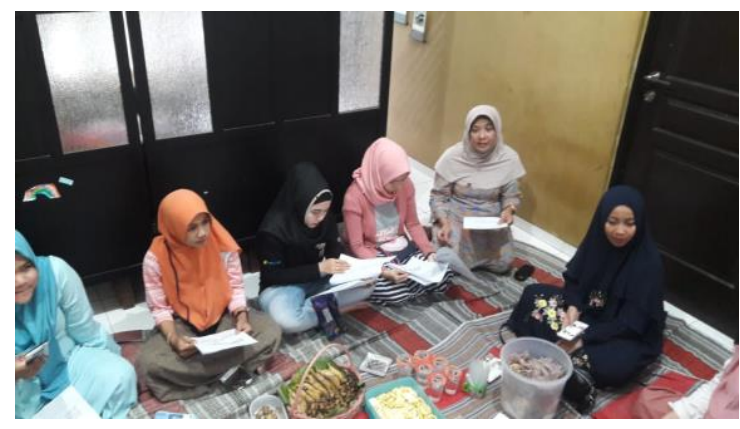

Gambar 2. Penjelasan Materi

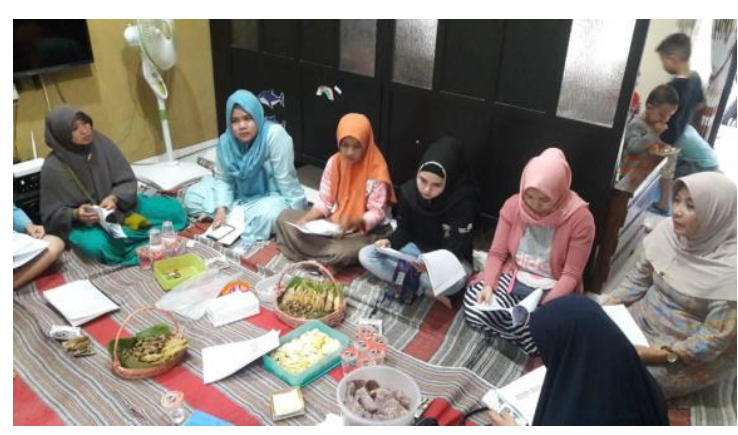

Gambar 3. Tanya Jawab

\section{V.PEMBAHASAN}

Keberhasilan Pengabdian Kepada Masyarakat ini belum dapat dilihat secara langsung, hal ini akan terlihat jika nanti diimplementasikan. Namun jika dilihat dari hasil yang dicapai maka manfaatnya adalah dengan bertambahnya, pengetahuan dan wawasan, ketrampilan yaitu dengan telah mendapat pengetahuan tentang transaksi elektronik diharapkan dapat membantu mereka dalam melakukan aktivitas pembelian secara online ketika terjadi kecurangan.

$$
\text { Dengan terselenggaranya Pengabdian }
$$

Dengan terselenggaranya Pengabdian Kepada Masyarakat ini dirasakan ada beberapa faktor pendorong yang menjadikan kegiatan ini dapat dilaksanakan dengan lancar,yaitu:

- Minat dan semangat para peserta dalam mengikuti pengabdian sangat besar sekali, sehingga mempermudah dalam proses belajar mengajar dan pemberian motivasi ,menyediakan tempat dan fasilitas yang memadai meskipun dalam kondisi yang sederhana.

- Pimpinan atau Ketua RW 20 Kelurahan Bunulrejo mempunyai tekad besar sehingga dapat 
mendorong kelancaran aktifitas Pengabdian Kepada Masyarakati, hal ini ditunjukkan antara lain menfasilitasi dengan menyediakan tempat, alat, meja dan kursi, soundsystem serta memberi kesempatan pada ibu-ibu anggota PKK RW 20 sebagai obyek yang digunakan untuk tempat praktek dalam pengabdian sampai dengan selesai.

- Pengajar/ Instruktur selalu siap dengan materi dan alat bantu (media) pengajarannya, misalanya: makalah , praktek, power point, ceramah, diskusi, tanya jawab hal ini memperlancar dalam pelaksanaan proses pengajarannya

\subsection{Luaran yang dicapai}

Setelah selesai kegiatan Pengabdian Kepada Masyarakat maka hasilnya dapat dievaluasi sebagai berikut:

- Acceptabilitas, Pengabdian yang diberikan mudah dikuasai oleh peserta, karena materinya bersifat praktis, hanya diperlukan ketekunan, ketelitian, kesabaran dan kreatifitas.

- Efektifitas, untuk kerja individu sangat memungkinkan sekali terutama bagi mereka yang mempunyai daya minat yang tinggi untuk mengembangkan bisnisnya.

- Ketepatan, ketrampilan yang diberikan sangat tepat sekali, karena mudah dipelajari dan berguna sebagai bekal dihari kelak.

\section{SIMPULAN DAN SARAN}

\subsection{Simpulan}

Setelah dilaksanakannya kegiatan Pengabdian Pada Masyarakat ini maka kegiatan pengabdian dan pengetahuan serta aplikasi yang sangat penting dalam rangka usaha untuk memperoleh tambahan pengetahuan dan wawasan tentang informasi transaksi elektronik. Partisipasi peserta sangat besar hal ini ditunjukkan dengan hadirnya 40 orang peserta dari total jumlah anggota PKK RW 20 kelurahan Bunulrejo Kota Malang yang aktif 30 orang yang ikut serta dalam pengabdian ini.

Berdasarkan hasil observasi selama kegiatan pengabdian berlangsung dapat dinilai bahwa $90 \%$ materi dapat diserap ( dimengerti dan dipahami ) oleh peserta Pengabdian Masyarakat. Hal ini ditunjukkan dengan sebagian besar peserta yaitu $93 \%$ dari 40 peserta yaitu 37 orang, memberikan pertanyaan tentang pentingnya informasi transaksi elektronik.

\subsection{Saran}

Agar supaya ilmu pengetahuan, Agar supaya ilmu pengetahuan, ketrampilan yang diberikan kepada masyarakat dan peserta pengabdian dapat lebih bermanfaat baik bagi diri sendiri maupun ibu-ibu PKK RW 20 kelurahan Bunulrejo Kota Malang maka semua komponen harus bekerja sama untuk mewujudkannya kegiatan bisnis dengan memperhatikan tenaga kerja di Lingkungan Sekitarnya khususnya dan di kota Malang pada umumnya.
Semua Informasi dan Pengetahuan yang di peroleh hendaknya dapat dipergunakan untuk memecahkan masalah, membuat keputusan yang dapat memberikan kepuasan kepada anggota organisasi

\section{DAFTAR PUSTAKA}

[1]. Ahmadi Miru \& Sutarman Yodo, Hukum Perlindungan Konsumen: Jakarta: PT Raja Grafindo Persada, 2007.

[2]. Erman Rajagukguk dkk, Hukum Perlindungan Konsumen, Bandung: Mandar Maju, 2000.

[3]. Gunawan Widjaja \& Ahmad Yani, Hukum Tentang Perlindungan Konsumen, Jakarta.

[4]. Shinta Dewi, Cyberlaw 1 Perlindungan Privasi Atas Informasi Pribadi Dalam E-commerce Menurut Hukum International, Bandung: Widya Padjajaran.

[5]. Undang-Undang Republik Indonesia Nomor 11 Tahun 2008 tentang Informasi Transaksi Elektronik.

[6]. Undang-Undang Republik Indonesia Nomor 8 Tahun 1999 tentang Perlindungan Konsumen.

[7]. Undang-Undang Republik Indonesia Nomor 39 Tahun 1999 tentang Hak Asasi Manusia. 